\title{
PENGARUH KONSUMSI SUPLEMEN VITAMIN C TERHADAP KADAR GLUKOSA DARAH PADA MAHASISWA FAKULTAS KEDOKTERAN UNIVERSITAS ISLAM AL - AZHAR TAHUN 2018
}

\author{
Sandiana Indrajat*, Ety Retno Setiyowati**, Sabariah**** \\ Fakutas Kedokteran Universitas Islam Al-Azhar \\ J1. Unizar No. 20 Turida Mataram \\ Email: hussabariah@yahoo.co.id
}

\begin{abstract}
ABSTRAK
Vitamin $\mathrm{C}$ adalah vitamin larut air, suplemen multivitamin antioksidan tinggi yang berfungsi melawan radikal bebas serta meregenerasi antioksidan lainnya. Tingginya radikal bebas berpengaruh terhadap fungsi endotel yang mengakibatkan terjadinya resistensi insulin dan berpengaruh terhadap jumlah glukosa darah. Tujuan : Mengetahui rerata kadar glukosa darah puasa, rerata kadar glukosa darah sewaktu setelah diberikan beban glukosa 75 g, glukosa darah sewaktu setelah pemberian konsumsi vitamin $\mathrm{C}$ dan mengetahui adanya pengaruh konsumsi suplemen vitamin $\mathrm{C}$ terhadap kadar glukosa darah mahasiswa Fakultas Kedokteran Universitas Islam Al - Azhar Mataram Tahun 2018. Metode Penelitian : Penelitian menggunakan metode preeksperimental dengan rancangan one grup pretest posttest design. Populasi adalah semua mahasiswa preklinik dengan sampel berjumlah 33 responden yang memenuhi kriteria inklusi. Teknik sampling menggunakan purposive sampling dengan uji statistik uji-t berpasangan. Hasil : Rerata glukosa darah puasa $85,18 \mathrm{mg} / \mathrm{dL}$, glukosa darah sewaktu setelah diberikan beban glukosa

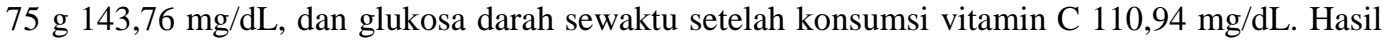
uji-t berpasangan diperoleh $\mathrm{p}$-value $=0,000(\mathrm{p}$ - value $\leq \alpha=0,01)$ dengan IK sebesar 19.210-46.426 $\mathrm{mg} / \mathrm{dL}$. Kesimpulan : Dari hasil uji t-berpasangan yang berarti terdapat pengaruh konsumsi suplement vitamin C terhadap kadar glukosa darah pada mahasiswa Fakultas Kedokteran Universitas Islam Al-Azhar Mataram Tahun 2018.
\end{abstract}

Kata Kunci : Glukosa Darah, Suplemen Vitamin C.

\section{PENDAHULUAN}

Dalam beberapa tahun terakhir, banyak iklan suplemen yang terdapat dalam berbagai macam media masa. Hal ini dipicu oleh kesadaran masyarakat akan pentingnya menjaga kesehatan. Oleh karena itu, banyak orang yang menginvestasikan uangnya bukan hanya untuk jasa asuransi kesehatan namun juga untuk membeli produk-produk suplemen (Utami \& Juniarsana, 2013).

Berdasarkan aplikasi, pasar global suplemen diet diklasifikasikan menjadi suplemen tambahan, suplemen obat, dan suplemen olahraga. Berdasarkan jenis bahan, suplemen diet dibagi menjadi tumbuh-tumbuhan, vitamin, asam amino, dan enzim. Pada tahun 2016 suplemen vitamin digunakan secara luas dan terhitung sekitar $42 \%$ dari pangsa pasar global. Asia-Pasifik merupakan pasar terbesar untuk suplemen diet pada tahun 2016. Hal ini didorong oleh peningkatan kesadaran konsumen untuk dapat merawat kesehatan dalam upaya tindakan preventif (Zion Market Research, 2017).

Menurut Anggota bidang Hubungan Internasional dan Hubungan Pemerintah Asosiasi Pengusaha Suplemen Kesehatan Indonesia (APSKI) mengungkapkan bahwa terjadi kenaikan penjualan sebesar $10 \%$ pada semester 
I2016. Pertumbuhan yang positif pada tahun 2016 juga diraih oleh PT. Indocare Citrapasific yang memproduksi suplemen vitamin $\mathrm{C}$ mencatatkan pertumbuhan penjualan disemester satu di atas dua digit (Sarnia, 2016).

\section{Mengkonsumsi}

suplemen

multivitamin menjadi gaya hidup sehat manusia modern. Mereka yang banyak melakukan aktivitas menjadikan suplemen multivitamin sebagai cara untuk meningkatkan stamina tubuh (Utami \& Juniarsana, 2013).

Dari berbagai macam vitamin yang ada dalam bentuk suplemen diet, vitamin C merupakan salah satu diantaranya. Vitamin $\mathrm{C}$, dikenal juga dengan asam askorbat merupakan vitamin larut air yang secara alami terdapat dalam makanan, dan tersedia sebagai suplemen. Vitamin C banyak dibutuhkan dalam berbagai macam biosintesis diantaranya kolagen, L-carnitine, neuro transmiter dan terlibat dalam proses metabolisme protein. Selain dibutuhkan dalam berbagai macan biosintesis dan proses metabolisme protein, vitamin $\mathrm{C}$ juga merupakan suatu antioksidan fisiologis yang penting dan terbukti meregenerasi antioksidan lainnya (U.S. Departement of Health \& Human Service, 2018).

Untuk dapat mengurangi dan melawan radikal bebas dibutuhkan antioksidan yang di produksi tubuh dan bisa kita dapatkan dari asupan nutrisi yang kita konsumsi. Diantara begitu banyak antioksidan alami yang bisa kita dapatkan dari makanan, vitamin $\mathrm{C}$ merupakan antioksidan yang baik dan bermanfaat dalam proses penurunan kadar glukosa darah (Purwaningtyastuti dkk. 2017). Mutiarani (2015) dalam penelitiannya yang berjudul pengaruh pemberian kromium, vitamin $\mathrm{C}$, dan vitamin $\mathrm{E}$ terhadap tikus wistar yang diinduksi aloksan mendapatkan nilai $\mathrm{P}<$ $\alpha(p=0,004)$ dengan rerata perubahan kadar gula darah kelompok kontrol sebesar $181 \mathrm{mg} / \mathrm{dl}$, sedangkan rerata kelompok vitamin C 118,75 mg/dl. Hal ini menerangkan bahwa pemberian vitamin $\mathrm{C}$ berpengaruh terhadap perubahan kadar gula darah. Kemampuan vitamin $\mathrm{C}$ sebagai antioksidan dapat menghambat pembentukan radikal bebas dan kerusakan sel di dalam tubuh, sehingga dapat memperbaiki kerusakan sel $\beta$ pankreas.

Menurut penilitian Afkhami \& Shojaoddiny (2007). Disebutkan bahwa terjadi pengurangan kadar glukosa darah yang signifikan pada kelompok pasien dengan diabetes tipe 2 yang diberikan suplemen vitamin C $1000 \mathrm{mg}$. Hal ini berhubungan dengan kemungkinan adanya peningkatan fungsi endothelial dan penurunan resisitensi insulin yang dipengaruhi oleh vitamin $\mathrm{C}$ sebagai antioksidan. Senada dengan Afkhami \& Shojaoddiny, penelitian yang dilakukan 
oleh Purwaningtyastuti dkk. (2017) tentang asupan vitamin $\mathrm{C}$ dengan kadar glukosa darah pasien rawat jalan DM tipe 2 juga menemukan hubungan yang bermakna antara asupan vitamin $\mathrm{C}$ dengan kadar glukosa darah pada pasien diabetes tipe 2, hal ini ditandai bahwa 92\% pasien dengan kadar glukosa darah tinggi merupakan pasien dengan asupan vitamin $\mathrm{C}$ tidak baik.

Sari (2007) dalam penelitiannya yang berjudul "Pengaruh Vitamin $\mathrm{C}$ (Ascorbic Acid) Terhadap Peningkatan Kadar Glukosa Dalam Darah Mencit" mendapati bahwa asupan vitamin $\mathrm{C}$ signifikan dapat meningkatkan kadar glukosa darah. Dimulai dengan dosis 500 mg, 1000 mg, 2000 mg, dan 3000 mg.

Berdasarkan latar belakang diatas yang menjelaskan semakin besarnya konsumsi vitamin $\mathrm{C}$ pada masyarakat awam dan hasil penelitian yang berbedabeda tentang manfaat vitamin $\mathrm{C}$ penulis tertarik untuk melakukan penelitian dengan judul "Pengaruh

Konsumsi Suplemen Vitamin C Terhadap Kadar Glukosa Darah Pada Mahasiswa Fakultas Kedokteran Universitas Islam Al - Azhar Mataram Tahun 2018".

\section{METODE PENELITIAN}

Berdasarkan masalah penelitian dan tujuan yang ingin dicapai, maka penelitian ini menggunakan metode eksperimen dengan design preeksperimental yang merupakan salah satu dari 3 design yang dapat digunakan dalam penelitian eksperimen. Pada design preeksperimental memiliki kelemahan karena masih terdapat variabel luar yang dapat mempengaruhi variabel terikat dan karena tidak adanya kelompok control pada penelitian (Styanto, 2006).

Sedangkan desain penelitian menggunakan pre-eksperimental dengan rancangan one group pretest posttest design. Dalam hal ini dilakukan pengukuran pada subjek penelitian (pretest) sebelum diadakannya perlakuan (treatment) dan melakukan pengukuran kembali setelah subjek diberi perlakuan (posttest). Teknik pengambilan sampel dilakukan secara non probability sampling yaitu purposive sampling. Pada penelitian ini ingin diketahui apakah terdapat pengaruh konsumsi suplemen vitamin $\mathrm{C}$ terhadap kadar glukosa darah (Sastroasmoro, 2008).

Pretest Treatment Posttest
$\mathrm{K}: \quad \mathrm{O} 1$
$\mathrm{X}$
$\mathrm{O} 2$

Keterangan :

$\mathrm{K}$ : Suatu kelompok yang telah melakukan puasa 10-12 jam, telah di cek kadar glukosa puasa, dan diberikan beban glukosa sebanyak $75 \mathrm{~g}$.

36

X : Perlakuan (konsumsi suplemen vitamin C) 
O1 : Mengukur kadar glukosa darah sebelum perlakuan

O2 : Mengukur kadar glukosa darah setelah perlakuan.

\section{Cara Kerja Pemeriksaan Glukosa Darah}

Adapun cara kerja pemeriksaan gukosa darah sebagai berikut: Peneliti meminta persetujuan subjek penelitian dengan mengisi dan menandatangani formulir informed consent, Menyiapkan perangkat glukometer yaitu uji strip, lancet, dan alkohol pad, Mencuci tangan dengan sabun dan memakai handscoon untuk mencegah.

Infeksi, Membersihkan daerah yang akan ditusuk (jari ketiga atau jari keempat) dengan alkohol pad, diamkan sebentar sampai alkohol kering, Menusuk jari dengan lancet, lalu ambil satu tetes darah untuk diperiksa, tunggu beberapa saat sampai hasil keluar, Mencatat hasil.

\section{HASIL DAN PEMBAHASAN}

\section{Hasil Penelitian}

Penelitian ini dilakukan di Lab Terpadu 2 Fakultas Kedokteran Universitas Islam Al-Azhar Mataram, Kelurahan Turide Timur, Kota Mataram, Nusa Tenggara Barat, dilaksanakan selama lima hari pada tanggal 1-5 Oktober 2018. Penelitian ini menggunakan metode pre-eksperimental. Sedangkan desain atau rancangan penelitian yang digunakan ialah one group pretest posttest design. Penelitian dilakukan dengan mengukur subjek penelitian (pre-test) sebelum diadakannya perlakuan (treatment) dan melakukan pengukuran kembali setelah diberi perlakuan (posttest). Sampel diambil dengan menggunakan teknik purposive sampling. Berdasarkan perhitungan, didapatkan sampel minimal sebesar 33 responden.

Sebelum melakukan penelitian, subjek penelitian sebelumnya telah diberikan penjelasan terkait tindakan yang akan dilakukan. Selain itu, telah dijelaskan pula untuk berpuasa, tidak mengkonsumsi obat-obatan, tidak beraktivitas fisik lebih dari 60 menit, serta tidak mengkonsumsi teh, kopi dan vitamin C. Pada saat penelitian, ditanyakan kembali kepada subjek penelitian apakah telah mengikuti semua penjelasan yang telah diberikan. Hal ini dilakukan untuk mengontrol variabelvariabel lain agar didapatkan hasil penelitian yang akurat.

Selanjutnya dilakukan pengukuran glukosa darah puasa, pengukuran glukosa darah sewaktu setelah diberikan beban glukosa $75 \mathrm{~g}$ dan pengukuran glukosa darah sewaktu setelah mendapatkan perlakuan dalam hal ini dengan mengkonsumsi vitamin C 2000 mg. Waktu yang dipakai masing-masing pengukuran berjarak 1 jam. Setelah semua data terkumpul, dilakukan analisis 
data dengan uji statistik yakni analisis univariat untuk mendeskripsikan masingmasing variabel dan analisis bivariat untuk mengetahui adanya pengaruh variabel bebas terhadap variabel terikat. Sedangkan untuk mengetahui pengaruh tersebut bermakna atau tidak, analisis statistik yang digunakan ialah uji-t berpasangan.

\section{Karakteristik Dasar Sampel}

Sampel penelitian ini adalah mahasiswa Fakultas Kedokteran Universitas Islam Al-Azhar Mataram berjumlah 33 responden yang memenuhi kriteria inklusi dan eksklusi.

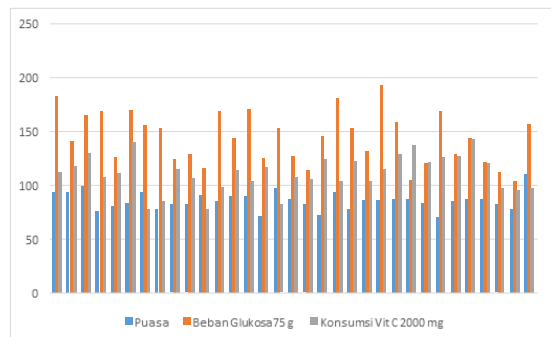

Gambar 4.1. Diagram Perbandingan Kadar Glukosa Darah Puasa, Kadar Glukosa

Darah Sewaktu Setelah Diberikan Beban Glukosa 75 g dan Kadar Glukosa Darah Sewaktu Setelah Diberikan Intervensi Konsumsi Vit C 2000 mg.

\section{Hasil Analisis Univariat}

\section{Karakteristik Dasar Sampel}

\section{Berdasarkan Jenis Kelamin Tabel}

\begin{tabular}{cccc}
\hline No. & Jenis Kelamin & Frekuensi & $\begin{array}{c}\text { Presentase } \\
(\%)\end{array}$ \\
\hline 1. & Laki-laki & 12 & 36.4 \\
2. & Perempuan & 21 & 63.6 \\
\hline & Total & 33 & 100 \\
\hline
\end{tabular}

Sumber : Data primer 2018 yang diolah oleh peneliti

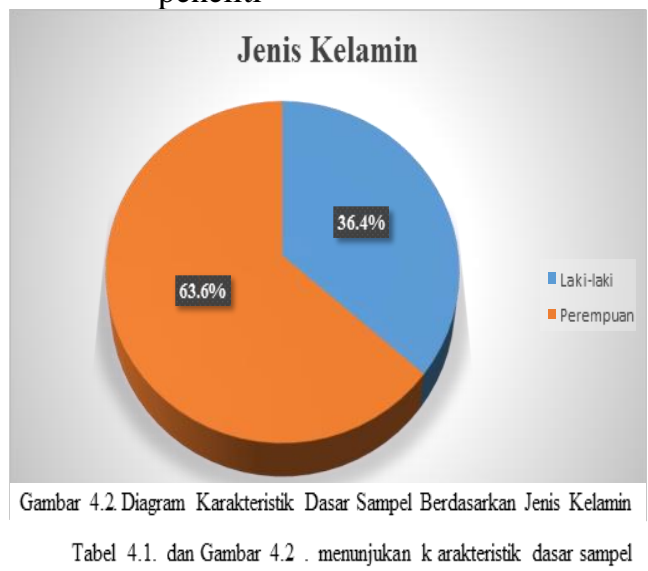

berdasarkan jenis kelamin. Dari total 33 sampel responden penelitian didapatkan 12 responden berjenis kelamin laki-laki $(36,4 \%)$ dan 21 responden berjenis kelamin Perempuan $(63,6 \%)$.

\section{Karakteristik Dasar Sampel Berdasarkan Usia Tabel}

\begin{tabular}{|c|c|c|c|c|}
\hline $\mathrm{No}$. & $\begin{array}{c}\text { Usia } \\
\text { (Tahun) }\end{array}$ & Freklunsi & Persentase $(\%)$ & $\begin{array}{l}\text { Rerinta } \\
\text { Usia (tahun) }\end{array}$ \\
\hline 1 & $18-20$ & 267 & 78.8 & \multirow{2}{*}{19.48} \\
\hline 2 & $21-23$ & & 21.2 & \\
\hline & Total & 33 & $100 \%$ & 19.48 \\
\hline
\end{tabular}

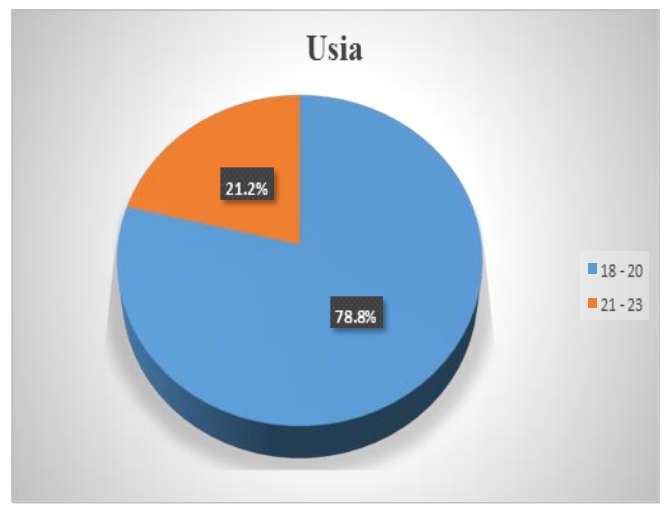

Gambar 4.3. Diagram Karakteristik Dasar Sampel Berdasarkan Usia.

Tabel 4.2. dan Gambar 4.3. menunjukan karakteristik dasar sampel berdasarkan 
usia responden. Dari total 33 sampel responden penelitian didapatkan 26 responden berusia antara 18-20 tahun $(78,8 \%)$ dan 7 responden berusia antara 21-23 tahun $(21,2 \%)$. Usia termuda pada sampel penelitian ini adalah 18 tahun sedangkan tertua adalah 23 tahun dengan rerata usia responden 19,48 tahun.

Rerata Kadar Glukosa Darah Puasa Sampel

Tabel 4.3. Rerata Kadar Glukosa Darah Puasa Sampel

\begin{tabular}{ccccc}
\hline No. & $\begin{array}{c}\text { Kadar Glukosa Darah } \\
\text { Puasa (mg/dL) }\end{array}$ & Frekuensi & $\begin{array}{c}\text { Persentase } \\
(\%)\end{array}$ & $\begin{array}{c}\text { Rerata } \\
(\mathrm{mg} / \mathrm{dL})\end{array}$ \\
\hline 1 & $70-85$ & 18 & 54.5 & \\
2 & $86-101$ & 14 & 42.4 & 85.18 \\
3 & $102-117$ & 1 & 3.1 & \\
\hline \multicolumn{5}{c}{ Total } \\
\hline \multicolumn{5}{l}{ Sumber : Data primer 2018 yang diolah oleh peneliti }
\end{tabular}

Tabel 4.3. merupakan data hasil penelitian yang dilakukan pada 33 responden untuk kadar glukosa darah puasa setelah berpuasa selama 10-12 jam. Dari hasil pengecekan yang dilakukan, didapatkan rerata kadar glukosa darah puasa $85,18 \mathrm{mg} / \mathrm{dL}$ dengan nilai kadar glukosa darah minimum $70 \mathrm{mg} / \mathrm{dL}$ dan nilai kadar glukosa maksimum 109 $\mathrm{mg} / \mathrm{dL}$.

Rerata Kadar Glukosa Darah Sewaktu Sampel Setelah Diberikan Beban Glukosa 75 g

Tabel 4.4. Rerata Kadar Glukosa Darah Sewaktu Sampel Setelah Diberikan Beban Glukosa $75 \mathrm{~g}$

\begin{tabular}{ccccc}
\hline No. & $\begin{array}{c}\text { Kadar Glukosa Darah } \\
\text { Sewaktu Setelah } \\
\text { Diberikan Beban } \\
\text { Glukosa } 75 \mathrm{~g}(\mathrm{mg} / \mathrm{dL})\end{array}$ & Frekuensi & $\begin{array}{c}\text { Persentase } \\
(\%)\end{array}$ & $\begin{array}{c}\text { Rerata } \\
(\mathrm{mg} / \mathrm{dL})\end{array}$ \\
\hline 1 & $104-119$ & 5 & 15.3 & \\
2 & $120-135$ & 9 & 27,1 & \\
3 & $136-151$ & 4 & 12,1 & 143.76 \\
4 & $152-167$ & 7 & 21.1 & \\
5 & $168-183$ & 7 & 21.1 & \\
6 & $184-199$ & 1 & 3.3 & \\
\hline \multicolumn{5}{c}{ Total } \\
\hline
\end{tabular}

Tabel 4.4. merupakan data hasil penelitian yang dilakukan pada 33 responden untuk kadar glukosa darah sewaktu 1 jam setelah diberikan beban glukosa 75 g. Dari hasil pengecekan yang dilakukan, didapatkan rerata kadar glukosa darah sewaktu setelah diberikan beban glukosa $75 \mathrm{~g}$ sebesar 143,76 mg/dL dengan nilai kadar glukosa darah minimum 104 mg/dL dan nilai kadar glukosa maksimum 192 mg/dL.

Rerata Kadar Glukosa Darah Sewaktu Sampel Setelah Diberikan Perlakuan Konsumsi Vitamin C 2000 mg.

Tabel 4.5. Rerata Kadar Glukosa Darah Sewaktu Sampel Setelah Diberikan Perlakuan Konsumsi Vitamin C 2000 mg.

\begin{tabular}{ccccc}
\hline & $\begin{array}{c}\text { Kadar Glukosa Darah Sewaktu } \\
\text { Setelah Diberikan Perlakuan } \\
\text { Konsumsi Vitamin C 2000mg } \\
(\mathrm{mg} / \mathrm{dL})\end{array}$ & Frekuensi & $\begin{array}{c}\text { Persentase } \\
(\%)\end{array}$ & $\begin{array}{c}\text { Rerata } \\
(\mathrm{mg} / \mathrm{dL})\end{array}$ \\
\hline 1 & $78-93$ & 4 & 12.1 & \\
2 & $94-109$ & 11 & 33.3 & \\
3 & $110-125$ & 11 & 33.1 & 110.94 \\
4 & $126-141$ & 6 & 18.2 & \\
5 & $141-157$ & 1 & 3.3 & \\
\hline \multicolumn{5}{c}{ Sumber : Data primer 2018 yang diolah oleh peneliti } \\
\end{tabular}

Tabel 4.5. merupakan data hasil penelitian yang dilakukan pada 33 
responden untuk kadar glukosa darah sewaktu 1 jam setelah diberikan perlakuan konsumsi vitamin C $2000 \mathrm{mg}$. Dari hasil pengecekan yang dilakukan, didapatkan rerata kadar glukosa darah sewaktu setelah diberikan perlakuan konsumsi vitamin C 2000 mg sebesar $110,94 \mathrm{mg} / \mathrm{dL}$ dengan nilai kadar glukosa darah minimum $78 \mathrm{mg} / \mathrm{dL}$ dan nilai kadar glukosa maksimum $142 \mathrm{mg} / \mathrm{dL}$.

Selisih Rerata Kadar Glukosa Darah Puasa Sampel dan Rerata Glukosa

\section{Darah Sewaktu Setelah Diberikan}

\section{Beban Glukosa 75g}

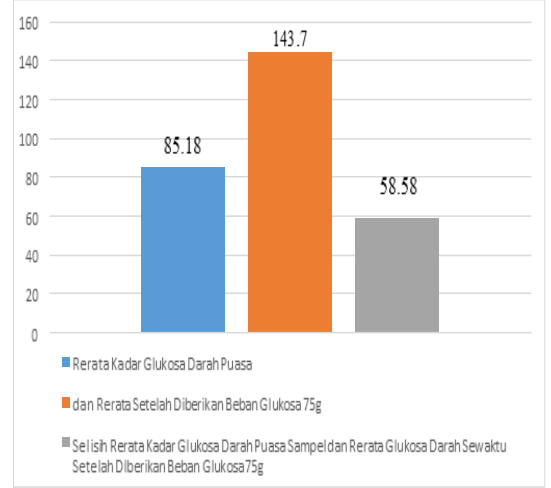

Gambar 4.4. Selisih Rerata Kadar Glukosa Darah Puasa Sampel dan Rerata Kadar Glukosa Darah Sewaktu Setelah Pemberian Beban Glukosa $75 \mathrm{~g}$

Sumber : Data primer 2018 yang diolah oleh peneliti.

Berdasarkan hasil penelitian dari 33 sampel, didapatkan selisih rerata kadar glukosa darah puasa dan rerata glukosa darah sewaktu sampel setelah pemberian beban glukosa $75 \mathrm{~g}$ sebesar 58,58 mg/dL.

Selisih Rerata Kadar Glukosa Darah Sewaktu Sampel Setelah Diberikan
Beban Glukosa 75 g dan Rerata Kadar

\section{Glukosa Darah Sewaktu Sampel}

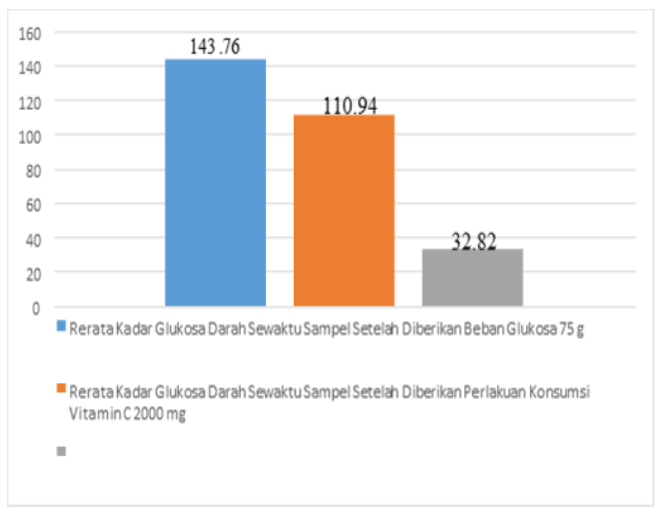

Gambar 4.5. Selisih Rerata Kadar Glukosa Darah Sewaktu Sampel Setelah Diberikan Beban Glukosa 75 g dan Rerata Kadar Glukosa Darah Sewaktu Sampel Setelah Diberikan Perlakuan Konsumsi Vitamin C $2000 \mathrm{mg}$

Sumber : Data primer 2018 yang diolah oleh peneliti.

Berdasarkan hasil penelitian dari 33 sampel, didapatkan selisih rerata kadar glukosa darah sewaktu sampel setelah diberikan beban glukosa $75 \mathrm{~g}$ dan setelah diberikan perlakuan konsumsi vitamin $\mathrm{C}$ $2000 \mathrm{mg}$ sebesar 32,82 mg/dL.

Penurunan Kadar Glukosa Darah Sampel Setelah Konsumsi Suplemen Vitamin C 2000 mg.

Tabel 4.6. Perubahan Kadar Glukosa Darah Sampel Setelah Konsumsi Suplemen Vitamin C $2000 \mathrm{mg}$.

\begin{tabular}{cccc}
\hline No. & Perubahan & Frekuensi & Persentrase $(\%)$ \\
\hline 1. & Penurunan & 31 & $94.0 \%$ \\
2. & Peningkatan & 2 & $6.0 \%$ \\
\hline & TOTAL & 33 & $100 \%$ \\
\hline
\end{tabular}

Sumber: Data primer 2018 yang diolah oleh peneliti 
Tabel 4.6. merupakan data hasil penelitian yang dilakukan pada 33 responden, didapatkan $31 \quad(94,0 \%)$ responden mengalami penurunan kadar glukosa darah setelah diberikan perlakuan konsumsi suplemen vitamin C $2000 \mathrm{mg}$ sedangkan $2(6,0 \%)$ responden lain mengalami peningkatan kadar glukosa darah.

\section{ANALISIS BIVARIAT}

Hasil Uji Normalitas Tabel

Table 4.7. Hasil Uji Normalitas

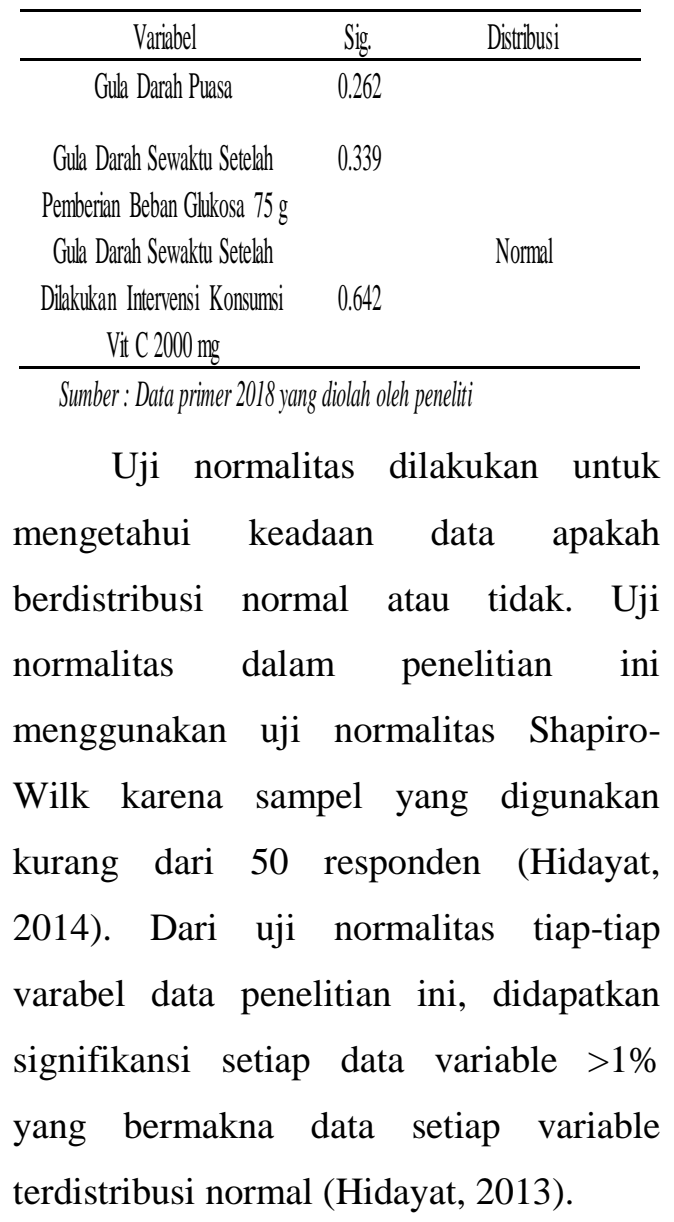

Hasil Analisis Bivariat Antar Variabel

Tabel 4.8. Hasil Analisis Bivariat Antar Variabel

\begin{tabular}{|c|c|c|c|}
\hline Variabel & Rerata $(\mathrm{mod} / \mathrm{L})$ & p Value & CI $99 \%$ \\
\hline $\begin{array}{l}\text { Kadar gukosa darah sebelum } \\
\text { perlakluan (setelah diberikan } \\
\text { beban gukosa } 75 \mathrm{~g} \text { ) } \\
\text { Kadar gukosa darah setelah } \\
\text { perlakuan (setelah dilakukan } \\
\text { intervensi konsumsi vit c } \\
\quad 2000 \mathrm{mg} \text { ) }\end{array}$ & $\begin{array}{l}143.76 \mathrm{mgdL} \\
110.94 \mathrm{mgdL}\end{array}$ & 0.000 & $19.210-46.426$ \\
\hline
\end{tabular}

Berdasarkan hasil perhitungan uji-t berpasangan menggunakan SPSS 23, diperoleh hasil nilai $\mathrm{p}$ sebesar 0,000 . Hasil ini menunjukkan bahwa penelitian ini memiliki nilai kemaknaan yang signifikan dikarenakan nilai $\mathrm{p}<0,01$, dengan kesimpulan bahwa Ho ditolak dan Ha diterima. Diterimanya $\mathrm{Ha}$ berarti dalam penelitian ini terdapat pengaruh yang signifikan konsumsi suplement vitamin $\mathrm{C}$ terhadap kadar glukosa darah pada mahasiswa Fakultas Kedokteran Universitas Islam Al-Azhar Mataram Tahun 2018.

Pada pengukuran kadar glukosa darah responden penelitian didapatkan nilai interval kepercayaan (IK) 99\% 19,210-46,426 mg/dL. Ini berarti jika dilakukan penelitian berulang kali dengan teknik sampling yang sama dengan populasi tersebut, akan didapatkan kepercayaan sebesar 99\% dengan rerata dari penelitian-penelitian tersebut berada dalam interval 19,210 sampai 46,426 $\mathrm{mg} / \mathrm{dL}$ dan nilai ekstrem hanya $1 \%$ dari kemungkinan. 


\section{Pembahasan}

Berdasarkan hasil penelitian, didapatkan rerata glukosa darah sewaktu sebelum diberikan perlakuan konsumsi vitamin C sebesar 147,76 mg/dL (kadar glukosa darah sewaktu setelah diberikan beban glukosa $75 \mathrm{~g}$ ). Sedangkan rerata glukoa darah sewaktu setelah diberikan perlakuan konumsi vitamin $\mathrm{C}$ sebesar $110,94 \mathrm{mg} / \mathrm{dL}$. Selisih rerata kadar glukosa darah sebelum dan setelah diberikan perlakuan konsumsi vitamin $\mathrm{C}$ ialah 32,82 $\mathrm{mg} / \mathrm{dL}$. Berdasarkan hasil perhitungan uji-t berpasangan menggunakan SPSS 23, diperoleh hasil nilai $\mathrm{p}$ sebesar 0,000 . hasil ini menunjukkan nilai $\mathrm{p}<0,01$ sehingga $\mathrm{Ho}$ di tolak yang berarti terdapat pengaruh yang signifikan konsumsi suplement vitamin $\mathrm{C}$ terhadap kadar glukosa darah pada mahasiswa Fakultas Kedokteran Universitas Islam Al-Azhar Mataram Tahun 2018. Nilai interval kepercayaan (IK) $99 \%$ dalam penelitian ini sebesar 19.210-46.426 mg/dL. Nilai IK ini menunjukkan jika dilakukan penelitianpenelitian berulang kali dengan teknik sampling yang sama pada populasi tersebut, akan didapatkan kepercayaan sebesar 99\% dengan rerata dari penelitian-penelitan tersebut berada dalam interval 19,210 sampai 46,426 $\mathrm{mg} / \mathrm{dL}$ dan nilai ekstrem hanya $1 \%$ dari kemungkinan.
Penurunan kadar glukosa yang terjadi setelah diberikan perlakuan konsumsi suplemen vitamin $\mathrm{C}$ pada 31 $(94,0 \%)$ responden penelitian ini berkaitan erat dengan vitamin $\mathrm{C}$ sebagai anti oksidan tinggi yang dapat mencegah dan mengurangi terjadinya stress oksidatif pada tubuh (Sinaga, 2016). Stress oksidatif sendiri salah satunya dapat menurunkan fungsi endotel bahkan dapat menyebabkan terjadinya disfungsi endotel yang banyak terjadi pada pasien yang mengalami diabetes tipe 2 (Afkhami \& Shojaoddiny, 2007). Ketika terjadi penurunan atau disfungsi endotel, akan mempengaruhi fungsi dari endotel salah satunya merupakan bagian yang berperan dalam pertukaran zat-zat ataupan bahan yang ada dalam darah ke sel dan jaringan sekitar melalui transport vesikel (Sherwood, 2011).

Dengan adanya vitamin $\mathrm{C}$ sebagai anti oksidan tinggi maka dapat mengurangi stress oksidatif yang mengakibatkan penurunan fungsi endotel sehingga transport vesikel yang terjadi dapat bekerja secara maksimal. Hal ini mengakibatkan rendahnya gula darah pada responden penelitian ketika dilakukan pengecekan setelah diberikan perlakuan konsumsi vitamin $\mathrm{C}$ sehingga mengakibatkan terjadinya penurunan gula darah pada responden setelah dilakukan perlakuan pemberian konsumsi suplemen vitamin $\mathrm{C}$. 
Untuk peningkatan kadar gula darah yang terjadi pada $2 \quad(6,0 \%)$ responden penelitian ini, kemungkinan berkaitan erat dengan pengaturan dari siklus menstruasi responden karena diketahui pada saat penelitian dilakukan responden yang bersangkutan tengah menjelang periode menstruasi bulanan.

Siklus menstruasi terdiri dari tiga fase, yaitu fase proliferasi, sekretori, dan menstruasi. Selama siklus menstruasi, terjadi fluktuasi hormon-hormon yang berperan dalam mengatur siklus, termasuk esterogen dan progesteron. Selama fase proliferasi, terdapat peningkatan kadar esterogen. Pada fase sekretori, kadar hormon esterogen dan progesteron meningkat. Sedangkan pada fase menstruasi, kedua hormon tersebut terdapat dalam kadar yang sangat rendah (Sherwood, 2011).

Fluktuasi hormon-hormon selama siklus menstruasi ini diduga menyebabkan perubahan kadar glukosa darah. Peningkatan kadar progesteron dikatakan dapat menyebabkan resistensi insulin temporer, sehingga menyebabkan kadar glukosa darah lebih tinggi dari normal (Bernard dan Kerure, 2013). Hal ini mengakibatkan tingginya gula darah pada responden penelitian ketika dilakukan pengecekan setelah diberikan perlakuan konsumsi vitamin C. sehingga mengakibatkan terjadinya peningkatan kadar gula darah pada responden yang disebabkan oleh meningkatnya kadar hormone progesterone yang memicu terjadinya peningkatan resistensi insulin.

Hasil penelitian ini mendapatkan adanya pengaruh yang signifikan antara konsumsi suplemen vitamin $\mathrm{C}$ terhadap kadar glukosa darah mahasiswa Fakultas Kedokteran Universitas Al-Azhar Mataram Tahun 2018 dengan menggunakan vitamin $\mathrm{C}$ dosis tinggi sebesar 2000 mg. Hasil penelitian ini sesuai dengan penelitian eksperimental yang dilakukan oleh Afkhami \& Shojaoddiny (2007) di Yadz Diabetes Reaserch Center, Yazd, Iran juga menunjukkan adanya penurunan glukosa darah pada subjek penelitian setelah pemberian suplement vitamin $\mathrm{C}$ dosis tinggi (1000 mg). Mereka juga mengemukakan bahwa pada penelitian yang dilakukan oleh Chen dkk. Tentang konsumsi suplement vitamin C $800 \mathrm{mg}$ tidak menimbulkan perubahan yang signifikan pada glukosa darah puasa dan serum insulin. Hal ini dimungkinkan karena penggunaan kadar vitamin $\mathrm{C}$ pada penelitian lebih rendah dari pada kadar yang mereka gunakan. Sedangkan menurut penelitian Purwaningtyastuti (2017) mengatakan bahwa terdapat hubungan antara asupan vitamin $\mathrm{C}$ dengan kadar glukosa darah. 


\section{Simpulan}

Berdasarkan hasil dan pembahasan mengenai pengaruh konsumsi suplement vitamin $\mathrm{C}$ terhadap kadar glukosa darah pada mahasiswa Fakultas Kedokteran Universitas Islam Al-Azhar Mataram tahun 2018, dapat di tarik kesimpulan sebagai berikut :

1. Rerata kadar glukosa darah puasa mahasiswa Fakultas Kedokteran Universitas Islam Al-Azhar Mataram Tahun 2018 sebesar 85,18 mg/dL.

2. Rerata kadar glukosa darah sewaktu mahasiswa Fakultas Kedokteran Universitas Islam Al-Azhar Mataram Tahun 2018 setelah diberikan beban glukosa $75 \mathrm{~g}$ sebesar $143,76 \mathrm{mg} / \mathrm{dL}$.

3. Rerata kadar glukosa darah sewaktu mahasiswa Fakultas Kedokteran Universitas Islam Al-Azhar Mataram Tahun 2018 setelah diberikan perlakuan konsumsi suplement vitamin C sebesar 110,94 mg/dL.

4. Terdapat pengaruh yang signifikan konsumsi suplemen vitamin $\mathrm{C}$ terhadap kadar glukosa darah pada mahasiswa Fakultas Kedokteran Universitas Islam Al-Azhar Mataram Tahun 2018.

\section{DAFTAR PUSTAKA}

Afkhami-Ardekani M., ShojaoddinyArdekani A. 2007. Effect of vitamin C on blood glucose, serum lipids \& serum insulin in type 2 diabetes patients. Indian $\mathbf{J}$ Med Res. 126(5):471-4.
American Diabetes Association. 2014. Diagnosing Diabetes and Learning about Prediabetes. http://www.diabetes.org/diabetesbas ics/diagnosis/. Diakses pada tanggal 30 Mei 2018.

Angelo G. 2015. Vitamin C. Linus Pauling Institute. https://lpi.oregonstate.edu/mic/vitam ins/vitamin-C diakses pada tanggal 27 Juli 2018.

Bernard, A.S., Kerure, S.B. 2013. Glucose Handling during Menstrual Cycle.

International Journal of Reproduction, Obstetrics and Gynecology. 2(3):284-287.

Champe, P.C. 2010. Biokimia Ulasan Bergambar Edisi 3. Jakarta: EGC.

Dorlan, Newman W.A. 2011. Kamus Kedokteran Dorlan Edisi 28. Jakarta: EGC.

Guyton A. C. 2007. Human Physiology and Mechanisms of Disease. Dalam : Andrianto, petrus. Fisiologi Manusia dan Mekanisme Penyakit. EGC. Jakarta.

Guyton A. C., Hall J. E. 2012. Buku Ajar Fisiologi Kedokteran Edisi 11. Jakarta: EGC.

Guyton A. C., Hall J. E. 2014. Buku Ajar Fisiologi Kedokteran Edisi 12. Singapore: Saunders Elsevier.

Hidayat Anwar. 2013. Pengertian Dan Rumus Uji Saphiro Wilk - Cara Hitung.

https://www.statistikian.com/2013/0 1/saphiro-wilk.html diakses pada tanggal 13 Desember 2018.

Hidayat Anwar. 2014. Shapiro Wilk Tabel. https://www.statistikian.com/2014/0 3/shapiro-wilk-tabel.html. diakses pada tanggan 13 Desember 2018.

Honarbakhsh S., Schachter M. 2009. Vitamin and Cardiocascular disease. Br J Nutr 101(8)1113-31. 
https://www.ncbi.nlm.nih.gov/pubmed/18 826726\% 20?dopt=Abstrac Diakses pada tanggal 23 Mei 2018.

Institute of Medicine. 2000. "Vitamin C" Dietary Reference Intakes for Vitamin C, Vitamin E, Selenium, and Carotenoids. Washington, D.C.:

The National Academies Press.

Hal. 95-185.

https://web.archive.org/read/9810/ch apter/7 diakses pada tanggal 26 Maret 2018.

Katzung, B. G. 2012. Farmakologi Dasar dan Klinik Edisi 10. Jakarta: EGC.

Kementrian Kesehatan Indonesia. 2014. Info Datin Situasi Dan Analisis Diabetes. Jakarta Selatan. Kementrian Kesehatan Ri Pusat Data Dan Informasi.

Lemon, P., Burke, K. 2002. Medical Surgical Nursing: Critical Thinking in Client Care. Jakarta.

Li Y., Schellhorn H.E. 2007. New developments and novel therapeutic perspectives for vitamin C. J. Nutr 137(10):2171-84

https://www.ncbi.nlm.nih.gov/pubm ed/17884994?dopt=Abstract diakses pada tanggal 27 Maret 2018.

Moshfegh A., Goldman J., Cleveland L. 2005. What We Eat in America NHANES 2001-2002 Usual Nutrient Intakes from Food Compared to Dietary Reference Intakes. Washington DC: U.S. Department of Agriculture, Agricultural Research Service.

Murray, R.K., Granner, D.K., Rodwell, V.W. 2009. Biokimia Harper. Jakarta: EGC.

Mutiarani A. L. 2015. Pengaruh Pemberian Kromium, Vitamin C, dan Vitamin E Terhadap Gula Darah Tikus Wistar Yang Diinduksi Aloksan. Jurnal Ilmiah Kedokteran 4(1), hal 39-50.

Notoatmodjo Soekidjo. (2010). Metodologi Penelitian Kesehatan.
Jakarta: EGC Rineka Cipta.

Nuffield Foundation. 2011. Measuring the Vitamin C Content of Foods and Fruit Juices. London.

https://web.archive.org/web/2017091406 3342/http://www.nuffieldfo undation.org:80/practicalbiology/measuring-vitamin-ccontentfoods-and-fruit-juices diakses pada 26 Maret 2018.

Price S. A., Wilson L. M. 2005. Patofisiologi Konsep Klinis ProsesProses Penyakit Volume 2. Jakarta: EGC.

Purwaningtyastuti R., Nurwanti E., Huda N. 2017. Asupan vitamin C berhubungan dengan kadar glukosa darah pada pasien rawat jalan DM tipe 2. Jurnal Gizi dan Dietik Indonesia. 5, (1), hal 44-49.

Sandoiu A. 2017. High-dose vitamin C make cancer treatment more effective, trial shows. Medical News Today.

https://www.medicalnewstoday.com /articles/316643.php diakses pada tanggal 27 Juli 2018.

Sari S. K. 2007. Pengaruh Vitamin C (Ascorbic Acid) Terhadap Peningkatan Kadar Glukosa Darah Mencit. Fakultas Kedokteran Universitas Kedokteran Maranatha Bandung. Karya Tulis Ilmiah.

Sarnia Pamela. 2016. Bisnis Suplemen Tumbuh Kian Sehat. Jakarta. Kontan.

http://industri.kontan.co.id/news/bisnissuplemen-tumbuh-kian-sehat diakses pada tanggal 27 Juli 2018.

Sastroasmoro S., Ismael S. 2008. DasarDasar Metodologi Penelitian Klinis. Jakarta: CV. Sagung Seto.

Sherwood Lauralee. 2012. Fisiologi Manusia Dari Sel ke Sistem. Jakarta: EGC.

Styanto A. E. 2006. Memperkenalkan Kembali Metode Eksperimen dalam Kajian Komunikasi. Jurnal ILMU 
KOMUNIKASI. 3(1): 37-48.

Sudoyo A.W., Bambang S., Idrus A. 2009. Buku Ajar Ilmu Penyakit Dalam Jilid III Edisi V. Jakarta: Interna Publishing.

Sugiyono. 2013. Metode Penelitian Kuantitati, Kualitatif, dan R\&D. Bandung: Alfabeta, CV.

Sutawardana H.J., Yulia., Waluyo A. 2016. Study Fenomenologi Pengalaman Penyandang Diabetes Militus yang Pernah Mengalami Episode Hipoglikemia. NurseLine Journal. 1(1): 159-175.

The Age-Related Eye Disease Study 2 (AREDS2) Research Group. 2013. Lutein + zeaxanthin and omega-3 fatty acids for age-related macular degeneration: the Age-Related Eye Disease Study 2 (AREDS2) randomized clinical trial. JAMA 310(2):208.

https://www.ncbi.nlm.nih.gov/pubmed/23 644932?dopt=Abstract diakses pada tanggal 30 Mei 2018.

U.S. Departement of Health \& Human Service. 2018. Vitamin C Fact Sheet for Health Professionals. https://ods.od.nih.gov/factsheets/Vit aminCHealthProfessional/\#en3.

Diakses pada tanggal 25 Maret 2018.

U.S. Department of Agriculture, Agricultural Research Service. 2011. USDA National Nutrient Database for Standard Reference. Release 24. Nutrient Data Laboratory.

https://www.ars.usda.gov/northeasta rea/beltsville-md-bhnrc/beltsville-

human-nutrition-

researchcenter/nutrient-data-

laboratory/. diakses pada 28 Maret 2018.

Utami P.A., Juniarsana I. W., 2013. Gambaran Tingkat Pengetahuan dan Tingkat Konsumsi Vitain (A, C, E) pada Ibu-ibu yang Mengkonsumsi Suplemen di Lala Studio. Jurnal
Skala Husada. 10, (2), hal 159-166.

Will cox B.J., Curb J.D., Rodriguez B.L. 2008. Antioxidant in cardiovascular healt and disease: key lessons from epidemiologic studies. Am J Cardiol 22;101(10A):75D-86D.

https://www.ncbi.nlm.nih.gov/pubm ed/18474278?dopt=Abstract. diakses pada tanggal 22 Mei 2018.

World Healt Organization 2017. Diabetes. http://www.who.int/mediacentre/fac tsheets/fs138/en/ Diakses pada tanggal 06 Mei 2018.

World Healt Organization. 2002. Human Fitamin and Mineral Requirements Rreport of a Joint FAO/WHO Expert Consultations Bangkok, Thailand. Roma.

http://www.fao.org/docrep/004/Y2809E/y $2809 \mathrm{e} 00 . \mathrm{htm} \#$ Contents diakses pada tnaggal 27 Maret 2018.

Yoshida M., Takashima Y., Inoue M., Iwasaki M., Otani T., Sasaki S., Tsugane S; JPHC Study Group. 2007. Prospective study showing that dietary vitamin $\mathrm{C}$ reduced risk of age-related cataracts in a middleaged Japanese population. Eur J Nutr 46(2):118-24. https://www.ncbi.nlm.nih.gov/pubm ed/17265171?dopt=Abstract diakses pada tanggal 30 Mei 2018.

Zion Market Research. 2017. Global Dietary Supplements Martket Will reach USD 220.3 Billion in 2022. https://globenewswire.com/newsrele ase/2017/01/11/905073/0/en/GlobalDietary-SupplementsMarket-willreach-USD-220-3-Billion-in-2022Zion-MarketResearch.html diakses pada tanggal 27 Juli 2018. 